\title{
Identifying Vulnerable Industries and Regions: The Proposed European Single Market and Portuguese Manufacturing
}

\author{
Pedro Telhado Pereira \\ Maria do Carmo Seabra
}

Faculdade de Economia

Universidade Nova de Lisboa

1000 Lisboa PORTUGAL

\begin{abstract}
This article presents a simple methodology for assessing the vulnerability of industries and regions in an environment of increasing wages. The analysis was motivated by the proposed European Single Market Act and the effects it will likely have on Portugal. The methodology shows that the most vulnerable industries are those with high labor intensity and low wages, a result that contrasts sharply with other studies. Due to the geographical concentration of these vulnerable industries, the regional consequences of European Community integration on Portuguese manufacturing will be considerable.
\end{abstract}

\section{Introduction}

Political authorities often argue that one of the reasons they cannot systematically take into account the economic impact of their decisions is that available methodologies to assess those impacts are very expensive and time consuming. The aim of this article is to present a simple methodology for assessing the vulnerability (i.e., the inability to sustain previous levels of employment) of different industries and regions in an environment of increasing wages. The approach used is a trade-off between theoretical sophistication and ease of empirical implementation. It was motivated by the need to assess the short-term impact of the European Single Market on Portuguese manufacturing industries and on regions of Portugal. The initial assumption of this analysis is that wages will increase in Portugal as a consequence of the liberalization of factor movements. Furthermore, this increase will be accompanied by a reduction in the dispersion of wages across industries. This means that lower wages will increase more than the average.

Vasco Santos, Diogo de Lucena, and Luís Cunha provided helpful suggestions on the original manuscript. The comments of Andrew Isserman and three anonymous referees were also useful.

Received 13 April 1992; in final revised form 7 June 1993. 
This article first presents the methodology then shows why wages will increase in Portugal. The results obtained by applying these methods to the Portuguese manufacturing industry are reported and then compared with results from the literature. The final section presents conclusions from the analysis and policy recommendations.

\section{Methodology}

To identify sector vulnerability in a situation of increasing wages, both supply and demand must be considered. An industry is vulnerable if its supply curve shifts upward substantially due to wage increases (supply vulnerability) and if this movement implies a large reduction in the quantities it can sell (market vulnerability).

Two indicators provide insight into the extent of the supply curve's shift. The first is the average wage rate in the sector. It is assumed that the lower this value, the larger the increase in wages will be, hence, the more vulnerable the sector. The second indicator is the proportion of labor costs to total output. The larger this proportion, the more the upward shift of the supply curve is associated with an increase in wages. Therefore, the sector is more vulnerable.

Market vulnerability depends on the elasticity of the demand curve faced by the industry. This demand is the difference between total demand (internal plus external demand) and external supply. The higher this elasticity, the more the decrease in output will be associated with a given shift in the supply curve, and the more vulnerable the sector will be. Global sector vulnerability, then, is determined by the average wage rate, the proportion of labor costs in total output, and the elasticity of the demand faced by the industry.

Vulnerable regions are determined by the importance of vulnerable industries within them. Total employment in vulnerable sectors is calculated for each region. The regional impact of the increase in wages depends on the proportion of regional workers employed in vulnerable industries.

\section{Why Wages Will Increase in Portugal}

Real Wages in Portugal are currently much lower than in the rest of the European Community. The gap has decreased since Portugal joined the European Community in 1986 (figure 1), but on average Portuguese real wages remain roughly 60 percent of the European Community average (Branco and Mello 1992).

This wage gap cannot persist in the long run. Increased labor mobility, brought on by implementation of the European Single Market Act, will cause wages in Portugal to rise. According to the Act, as of 1 January 1993, Portuguese workers can live and work in any European Community country they wish under the same conditions enjoyed by that nation's workers. Restrictive immigration 
FIGURE 1

Ratio of Portugal's Real Wages to Average Real Wages in Europe, 1965-88

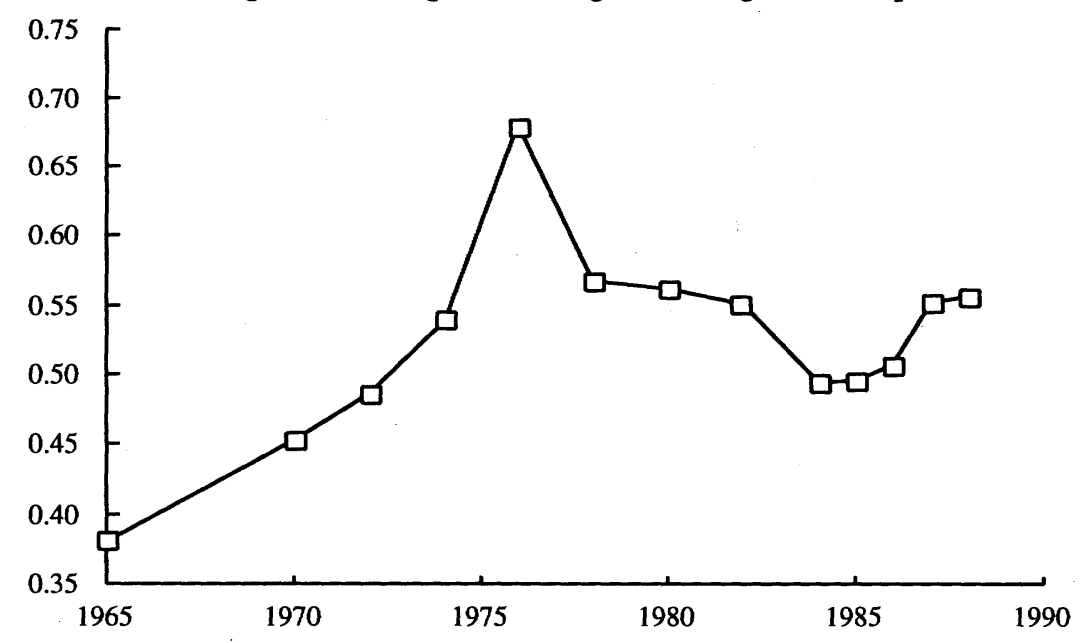

Source: Branco and Melo 1992

policies will no longer apply to workers from European Community countries.

Moving costs for Portuguese workers have traditionally been low and have contributed to the country's high emigration rates over the past few decades (Barosa and Pereira 1992). Between 1965 and 1973, more than 100,000 people emigrated each year, mostly to European Community countries (figure 2). These large flows decreased sharply after 1974 due to the restrictive immigration policies adopted by the northern European Community countries as a consequence of the 1973 oil crisis. Barosa and Pereira's (1992) analysis suggests, however, that without these restrictions, the outflow of labor from Portugal would have continued, and emigration at the beginning of the $1980 \mathrm{~s}$ would have been higher than it was in the early 1970s. Though on a smaller scale, emigration has continued until there are now more than 1 million Portuguese immigrants in European Community countries, which represents more than 10 percent of the current Portuguese population.

Theory predicts, and the available empirical analyses confirm, that the uncertainty costs associated with emigration decrease as the number of emigrants in the destination country increases (Barosa and Pereira 1989, 1992; Pereira 1989). Moreover, the emigration rate is positively related to income in the destination country and negatively related to wages in the home country. Hence, the existing wage differential is enough to induce Portuguese emigration when the immigration policies in the destination countries change as a consequence of the European Single Market Act. 
FIGURE 2

Emigration from Portugal, 1960-88

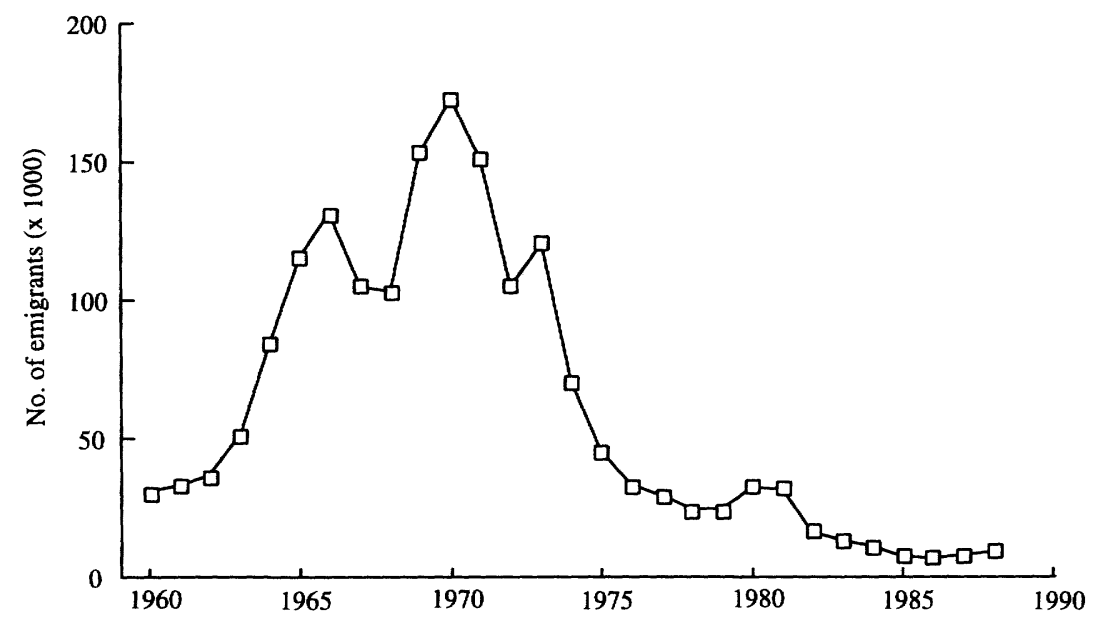

Some would argue that the current international situation is causing a high influx of East European workers into European labor markets, which will inhibit immigration from Portugal into these markets. Due to the "non-discrimination rule" in the proposed Single Market Act, however, Portuguese workers, coming from a Community country, will now be in a more favorable position than they were before. Also, the flow of Eastern European workers will probably be controlled in the near future. Hence, a significant outflow of labor from Portugal is predicted.

The recent example of East Germany's integration with the West supports these predictions. Using an overlapping generations model with endogenous choice of location, Raffelhuschen (1992) estimated that in a steady-state equilibrium characterized by current economic conditions, net migration from the East would amount to 45 percent of the labor force. Burda and Wyplosz (1992) showed that, from the opening of the frontier in November 1989 until the end of 1990, about 6 percent of the entire Eastern labor force had moved into the West. They predicted that by the end of 1991 , roughly 5 percent of the ex-East German population and 10 percent of its entire labor force would have migrated west.

The German case may be peculiar, though, because psychological and cultural obstacles to emigration are lower than in other countries due to the common language shared by sending and host regions. Nevertheless, 4 million Portuguese living abroad - including 1.2 million in Brazil; 760,000 in France; 600,000 in South Africa; and 380,000 in the United States - demonstrates a propensity for the Portuguese to emigrate. And, the social obstacles to emigration are 
lessened by the large numbers of Portuguese immigrants already living in European Community cities in Portuguese neighborhoods.

As in Germany, the actual level of Portuguese emigration will also depend on the verified level of capital inflow. Either by an upward shift of the supply curve (i.e., a decrease in domestic labor) or by an upward shift of the demand for labor (or both), real wages in Portugal will increase. This is, in fact, what economic theory predicts in a context of labor mobility and low migration costs (McConnel and Brue 1989; Ehrenberg and Smith 1988; Elliott 1991). Furthermore, since manufacturing wage dispersion is smaller in other European Community countries than in Portugal, lower wages are expected to increase more than higher wages.

\section{Applying the Methodology to Portugal}

\section{Industry Analysis}

Due to the pattern of specialization in Portuguese manufacturing, it was hypothesized that the increase in wages in manufacturing industries will deeply affect most of the regions in Portugal. Therefore, a lower bound for the number of workers affected by the new environment was established. All manufacturing sectors that employed more than 3,000 workers or had a value added greater than 7 billion escudos in 1987 were selected. ${ }^{1}$ Thirty-one sectors met these criteria, accounting for 80 percent of the value added and 79 percent of the total employed in manufacturing industries.

For each sector, the average wage rate and the proportion of labor costs to total output were calculated. The total wages paid, divided by the total number of workers for each sector, gave the average wage rate. The two indicators were also calculated for the manufacturing industry as a whole. Table 1 presents the values of these supply vulnerability indicators and the rank of each sector based on the individual indicators.

The 31 selected sectors are plotted in figure 3 according to their supply vulnerability ranks. The whole-industry average is represented by the intersection of the two internal axes. All sectors in the lower left quadrant are very supply vulnerable (Fish Canning, Wool, Cotton, Knitting, Clothing, Carpets, Jute, Footwear, Lumber, Carpentry, Cork, Furniture, Plastic goods, Ceramics, Brick \& pottery, Tools \& metal articles, and Bread). Furniture, for example, is shown to be very vulnerable to wage increases. It pays very low wages, and labor costs have a significant weight in output value. In the opposite quadrant, the Industrial chemicals sector shows high wages and low dependence of technology on labor input.

\footnotetext{
' Data were collected from the Portuguese Bureau of Statistics (Instituto Nacional de Estatística 1987) and the classification system used here, Classificação das Actividades Económicas (CAE), is the same as theirs.
} 
TABLE 1

Summary of Manufacturing Industry Analysis

\begin{tabular}{|c|c|c|c|c|c|c|}
\hline \multirow[b]{3}{*}{ Sector } & \multicolumn{4}{|c|}{ Supply vulnerablilty } & \multirow{2}{*}{\multicolumn{2}{|c|}{$\begin{array}{c}\begin{array}{c}\text { Market } \\
\text { vulnerablility }\end{array} \\
\text { (Exp + Imp) / output }\end{array}$}} \\
\hline & \multicolumn{2}{|c|}{ Average Wage } & \multicolumn{2}{|c|}{ Wages/output } & & \\
\hline & Value $^{\mathrm{a}}$ & Rank & Value $^{b}$ & Rank & Value $^{b}$ & Rank \\
\hline Fish canning & 507 & 5 & 20.7 & 11 & 96.4 & 8 \\
\hline Wool & 625 & 12 & 24.0 & 9 & 46.3 & 21 \\
\hline Cotton & 596 & 9 & 18.5 & 18 & 42.3 & 22 \\
\hline Knitting & 562 & 8 & 16.8 & 24 & 80.0 & 12 \\
\hline Carpets & 635 & 14 & 18.0 & 20 & 57.2 & 19 \\
\hline Jute & 628 & 13 & 20.5 & 12 & 75.6 & 13 \\
\hline Clothing & 550 & 7 & 21.0 & 10 & 171.6 & 2 \\
\hline Footwear & 532 & 6 & 18.0 & 20 & 155.2 & 4 \\
\hline Lumber & 489 & 4 & 19.0 & 16 & 65.0 & 16 \\
\hline Carpentry & 487 & 3 & 20.0 & 14 & 29.5 & 24 \\
\hline Cork products & 612 & 10 & 17.0 & 23 & 115.8 & 6 \\
\hline Furniture & 470 & 2 & 28.0 & 4 & 53.6 & 20 \\
\hline Industrial chemicals & 1431 & 30 & 6.8 & 31 & 101.1 & 7 \\
\hline Agricultural chemicals & 1533 & 31 & 15.0 & 25 & 23.1 & 25 \\
\hline Pharmaceutical goods & 1230 & 27 & 19.2 & 15 & 85.1 & 11 \\
\hline Plastic goods & 801 & 18 & 17.6 & 22 & 58.3 & 18 \\
\hline Ceramics & 747 & 16 & 30.9 & 2 & 94.0 & 9 \\
\hline Glass & 1160 & 23 & 26.5 & 6 & 69.3 & 15 \\
\hline Brick \& pottery & 614 & 11 & 29.0 & 3 & 18.2 & 26 \\
\hline Iron \& steel & 1581 & 32 & 18.1 & 19 & 119.7 & 5 \\
\hline Tools \& metal articles & 646 & 15 & 25.1 & 8 & 17.1 & 27 \\
\hline Other metal articles & 837 & 20 & 25.9 & 7 & 71.0 & 14 \\
\hline \multicolumn{7}{|l|}{ TVs, radios, \& telecom- } \\
\hline munications equip. & 1222 & 26 & 20.2 & 13 & 222.0 & 1 \\
\hline Steel, shipbuilding, \& repair & 1185 & 25 & 57.6 & 1 & 41.5 & 23 \\
\hline Motor vehicles & 1386 & 29 & 9.2 & 29 & 170.0 & 3 \\
\hline Beer & 1250 & 28 & 12.5 & 27 & 5.2 & 30 \\
\hline Animal feeds & 968 & 22 & 3.2 & 32 & 1.1 & 32 \\
\hline Paper products & 1173 & 24 & 10.0 & 28 & 64.5 & 17 \\
\hline Dairy products & 785 & 17 & 9.0 & 30 & 10.9 & 29 \\
\hline Bread & 458 & 1 & 19.0 & 16 & 1.5 & 31 \\
\hline Graphics & 907 & 21 & 27.0 & 5 & 15.0 & 28 \\
\hline TOTAL & 801 & 18 & 15.0 & 25 & 85.6 & 10 \\
\hline
\end{tabular}

${ }^{a}$ Average wage is expressed in Portuguese escudos $(\times 1000)$

${ }^{b}$ The other two values are expressed as percentages. 
FIGURE 3

Supply Vulnerability

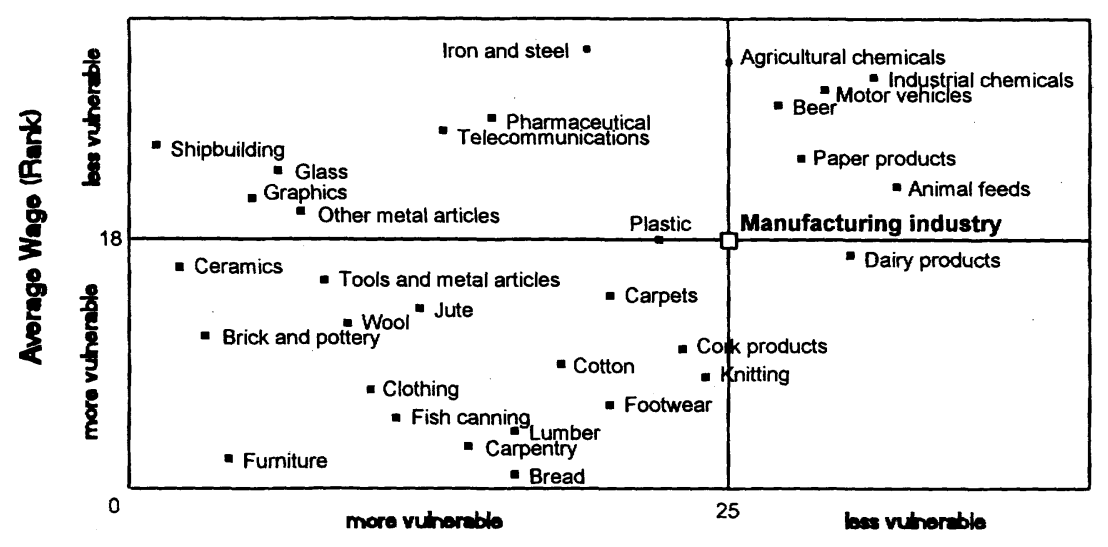

Weges/output (Rank)

As mentioned before, market vulnerability should be measured by the elasticity of demand faced by Portuguese firms. There are, however, no empirical studies of these elasticities for the Portuguese economy. As a sufficient condition for market vulnerability, the weight of the sum of exports plus imports (i.e., net exports) on the value of total output was used. The rationale for using this value is shown in the Appendix. The values for the rate of foreign trade and the degree of market vulnerability are presented in table 1 . Based on this indicator, the sectors of Bread, Carpentry, Brick \& pottery, and Tools \& metal articles were excluded from further analysis. The remaining supply-vulnerable sectors are all highly traded (i.e., foreign trade accounts for more than 40 percent of output) and are therefore market-vulnerable as well. After this selection, 42.6 percent of the total manufacturing employment and 28.3 percent of the total value added remained under study.

\section{Regional Analysis}

Since mainland Portugal is administratively divided into 18 regions, the regional analysis was conducted at this level of disaggregation. To determine the effects of an integrated European market on Portugal's regions, the vulnerable industries identified above were considered. The localization of the different industries was analyzed whenever the number of workers in a particular industry in a specific 
region was greater than 300 and there were more than two firms in the region. ${ }^{2}$ With these restrictions, the vulnerable industries analyzed accounted for 264,897 workers, or 43 percent of the employment in Portuguese manufacturing.

Vulnerable regions in Portugal were determined by comparing employment in vulnerable activities with total regional employment. The distribution of total employment shows a very large regional imbalance, with six coastal regions accounting for more than $\mathbf{7 0}$ percent of total employment (figure 4). Regional employment in vulnerable manufacturing industries is particularly concentrated in Porto and Braga (figure 5). These two regions account for nearly 60 percent of Portugal's vulnerable workers. Figure 5 also shows the weight of vulnerable employment in a region's total manufacturing employment. In Braga and Castelo Branco, almost 80 percent of manufacturing employment is in vulnerable industries. In five other regions (Guarda, Porto, Coimbra, Aveiro, and Leiria), more than $\mathbf{4 0}$ percent of manufacturing employment is in a fragile situation. The industrial sectors that are more concentrated in these regions are the textile industries, footwear, wood and cork, furniture-making, ceramics and glass, and telecommunications equipment.

The analysis here is not aimed at addressing the problem of regional imbalances in Portugal, but rather at identifying a threshold of vulnerability where manufacturing employment will cause regional problems as a result of the European Single Market. This analysis shows that the less-developed regions of Portugal (Vila Real, Bragança, and Beja) have no vulnerable employment (figure 5), largely because their combined total employment is less than 6 percent of Portugal's total (figure 4). Thus, as far as manufacturing is concerned, these regions will not be adversely affected by the European Single Market. Moreover, the expected increase in European Community structural funds will probably lessen the regional imbalances in Portugal, especially if a significant portion is applied to improving roads and other infrastructure (Seabra and Pereira 1991).

Figures 6 and 7 show the proportion of each region's total employment occupied in vulnerable activities. The overall ratio for mainland Portugal is 10 percent. Six regions of Portugal (Braga, Castelo Branco, Aveiro, Guarda, Porto, and Leiria) employ more than 10 percent of their labor force in industries vulnerable to an environment of increasing wages. Coimbra is slightly better off because employment in manufacturing represents a smaller percentage of total regional employment. In Lisbon (Lisboa) and Setúbal, the high concentration of services and capital-intensive industries lessens the overall impact of increased wages.

\footnotetext{
${ }^{2}$ Data are not published when there are two or fewer firms in a region.
} 


\section{FIGURE 4}

Distribution of Employment in Mainland Portugal and the Regional Proportion of Total Employment, 1985

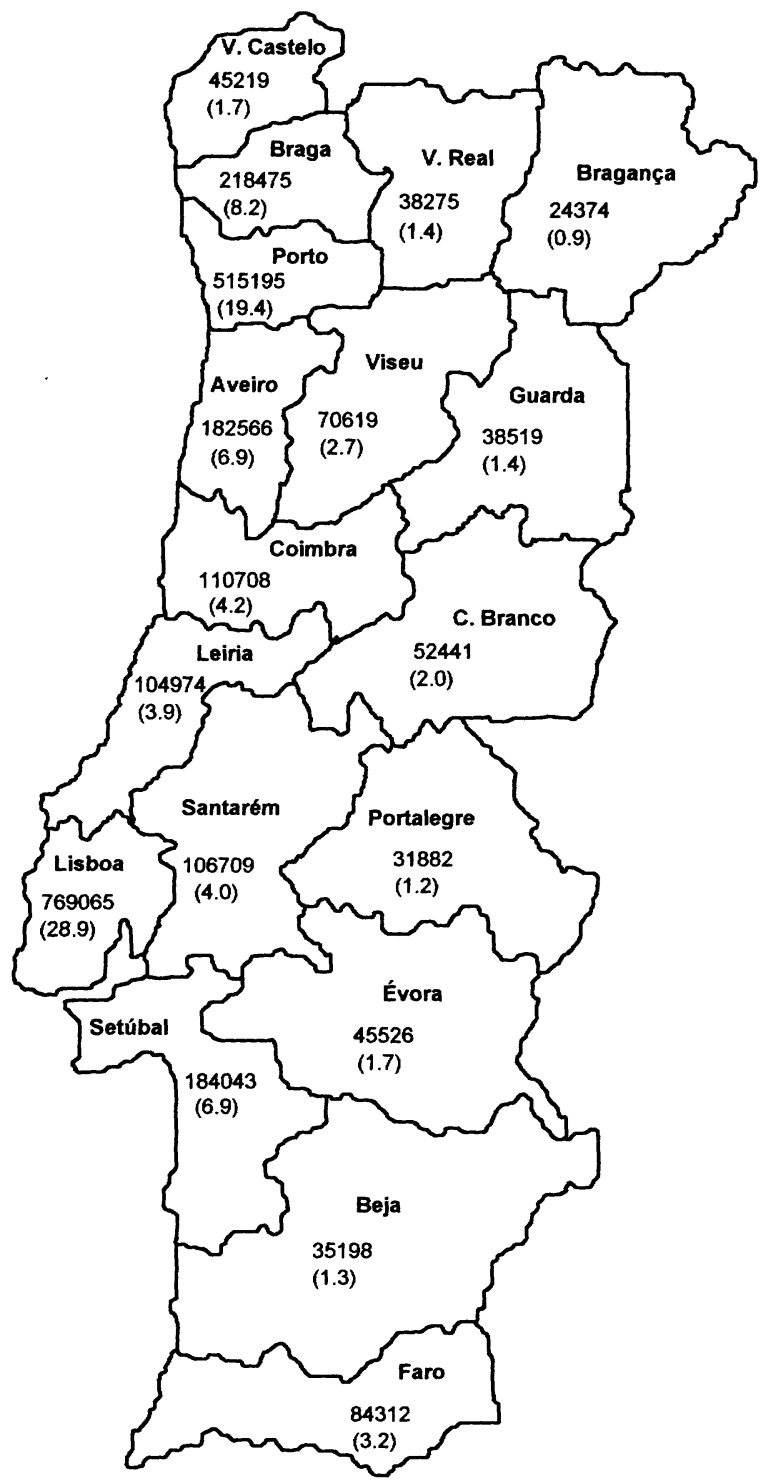

Total Employment (Mainland Portugal): 2,658,100 
FIGURE 5

Distribution of Portuguese Employment in Vulnerable Manufacturing Industries and the Proportion of Regional Manufacturing Employment Represented, 1987

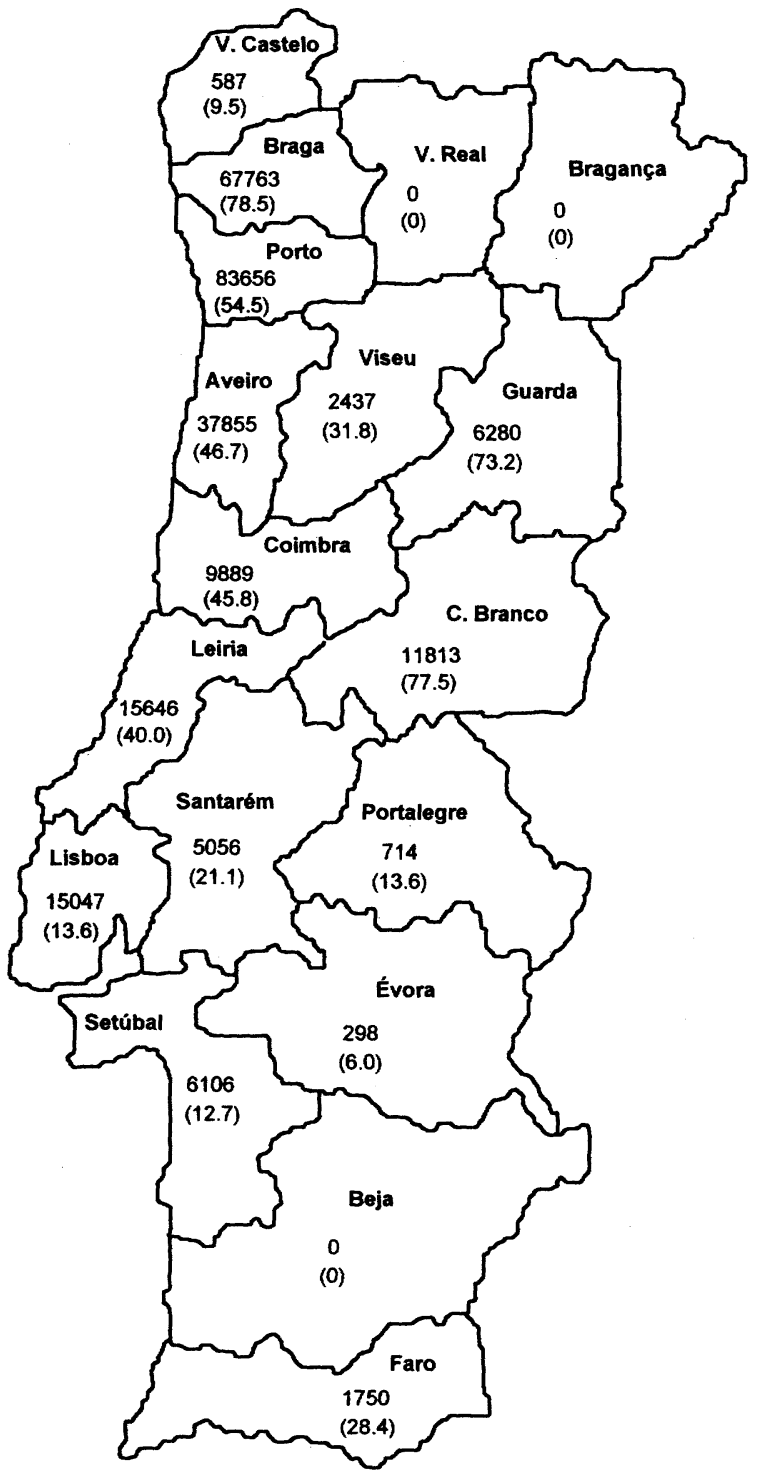

Total Manufacturing Employment (Mainland Portugal): 621,150

Vulnerable Manufacturing Employment: 264,897 (43 percent) 


\section{FIGURE 6}

Vulnerable Manufacturing Employment as a Percentage of Total Regional Employment, 1987*

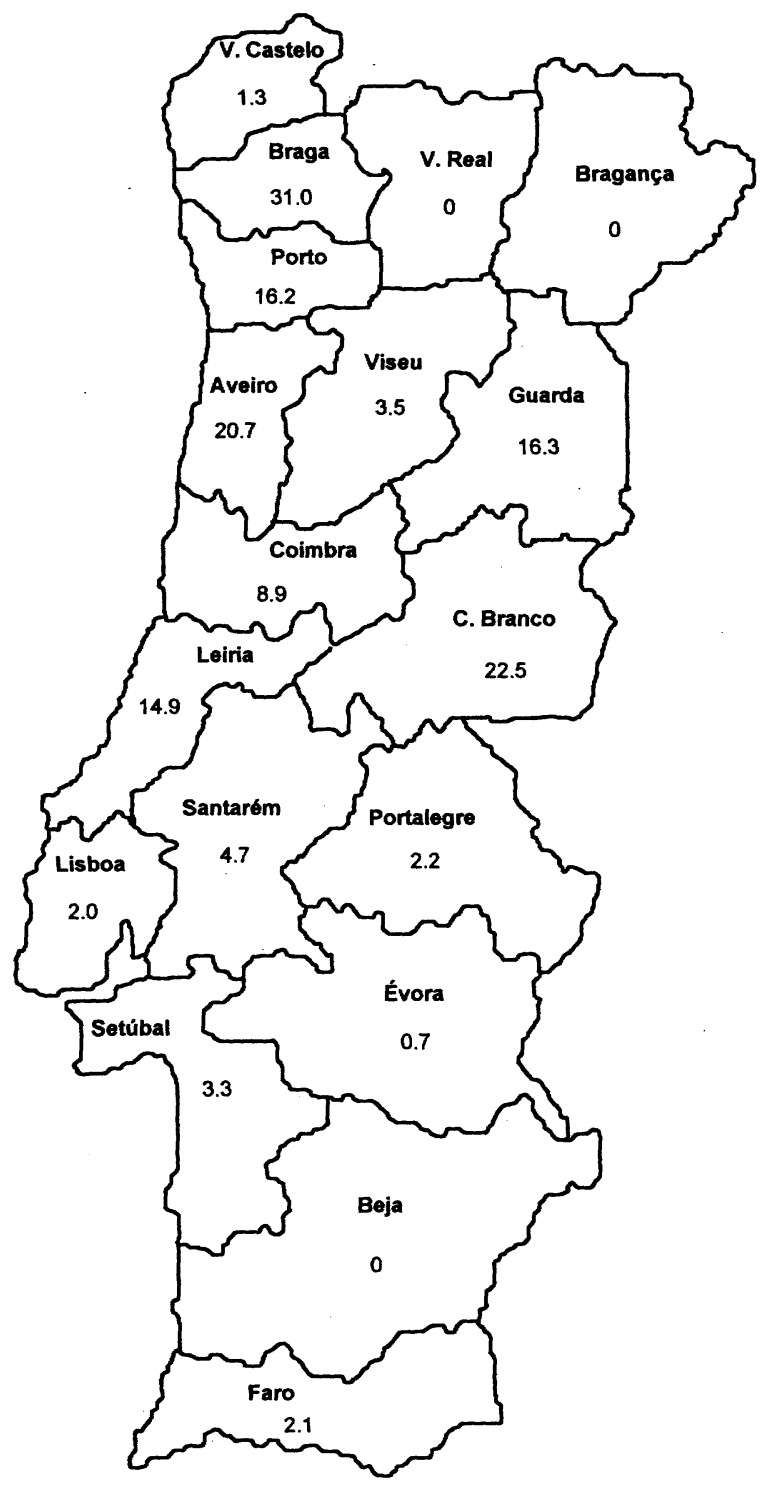

Mainland Portugal: 10 percent employed in vulnerable manufacturing industries

* Though data on overall employment is for 1985 and data for employment in vulnerable industries is for 1987 , total employment probably did not change substantially between these two years. 
FIGURE 7

Regions Grouped by the Proportion of Regional Employment Affected by the European Single Market, 1987

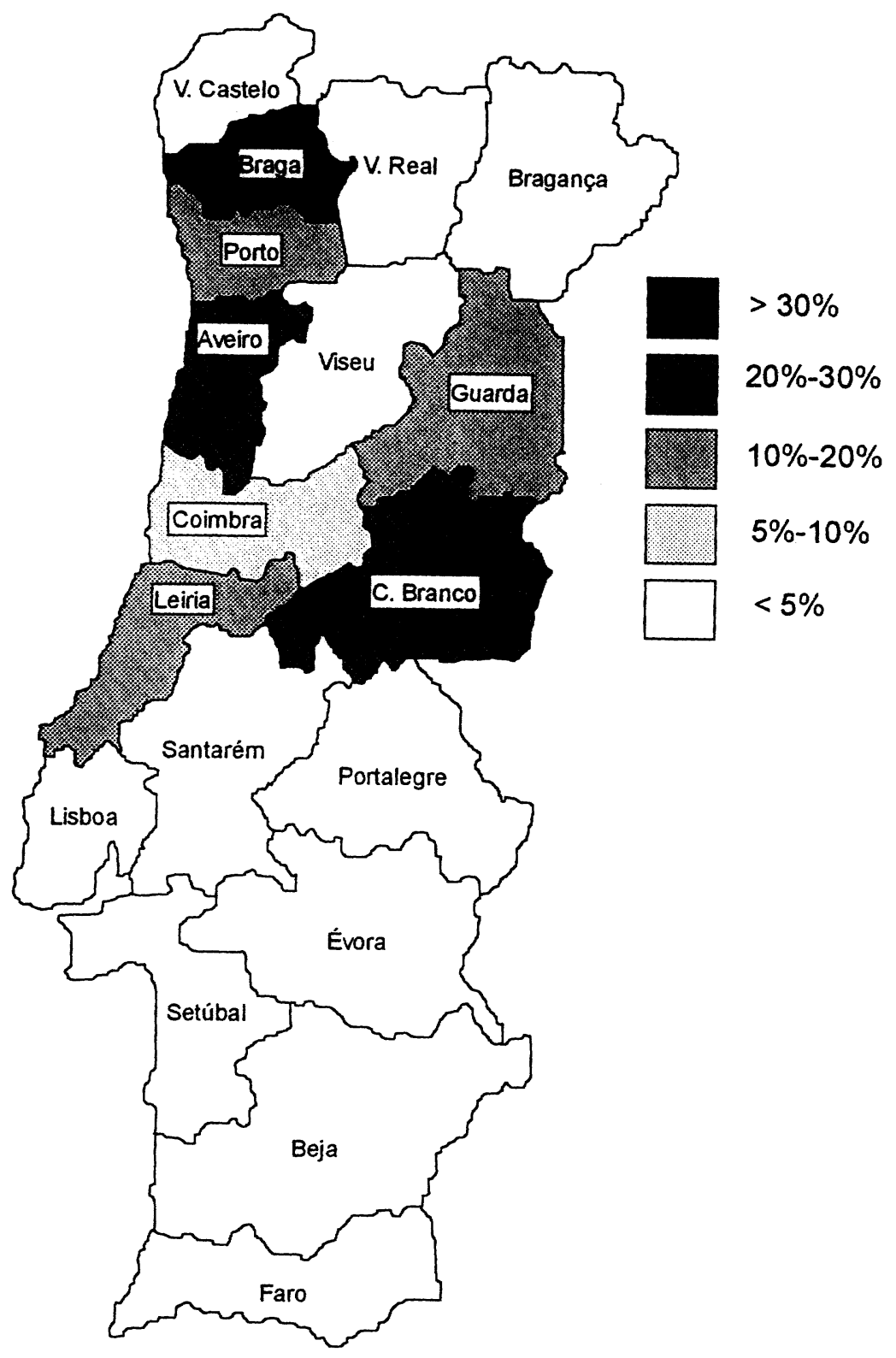




\section{Comparison with the Existing Literature}

Most of the literature on the consequences of Portugal's integration into the European Community focuses on the trade effects of opening the market for goods and services. Several authors estimate the effects of an integrated market on trade creation and trade diversion, implicitly assuming immobility of production factors (Corado and Melo 1985; Plummer 1991). ${ }^{3}$ The results of these analyses suggest that there might be significant trade creation as a consequence of integration, namely, in the industries of transport equipment, electrical machinery, other chemical products, clothing, and other textiles. This trade creation could induce short-run adjustment costs.

Other studies, using similar assumptions about labor mobility, try to assess the competitive position of the Portuguese manufacturing industry relative to the rest of the European Community. Donges and Schatz $(1985,1989)$, following a product-by-product analysis of the evolution of trade patterns, conclude that Portugal enjoys comparative advantage in manufactured products with a high input of unskilled labor or a low technological content. Hence, Textiles, Footwear, Electronics, Wood, Cork products, and Ceramics emerge as the sectors where Portugal has the best chance for specialization after market integration. Buigues, Ilzkovitz, and Lebrun (1990) calculate the degree of protection still existing in each manufacturing sector and similarly conclude that the sectors which are less vulnerable to integration are basically the labor-intensive ones.

All of these results contrast sharply with the results of this study. The differences are due to the explicit consideration here of factor market integration, specifically, labor mobility. Once the assumption of international factor immobility is relaxed, factor endowments are no longer given, and comparative advantage has to be re-analyzed. In short, while others claim that traditional exporting sectors (i.e., labor-intensive ones) are already very open and should face no major shocks from increased openness, the contention here is that these sectors are the most vulnerable precisely because they are highly tradable and labor-intensive.

\section{Conclusions and Policy Recommendations}

The proposed European Single Market will entail total liberalization of factor movements across European Community countries' borders. With increased labor mobility must come a reduction in the wage gap between Portugal and its European Community partners. Because Portugal is relatively small, real wages there will, in the long run, increase.

${ }^{3}$ Similarly, Martin (1991) assumes immobility of the labor force in his Canadian research. The method of Markusen, Noponen, and Driessen (1991) shows the vulnerability of regions to past trade flows but cannot incorporate the effects of future wage changes. 
A significant part of Portuguese manufacturing employment is working in industries that pay very low wages and in which labor costs are a high proportion of output value. These sectors are highly vulnerable to wage increases. Moreover, several of these industries produce highly tradable goods and, hence, face elastic demands.

This analysis suggests that at least one out of two employees in Portuguese manufacturing, or one of every ten workers, are in industries with low wages and high relative labor costs. These proportions represent lower bounds for the number of workers affected by the new economic conditions brought about by the European Single Market. ${ }^{4}$

Industries that will have trouble adapting to wage increases are distributed unevenly across the Portuguese territory. In some regions - namely, Braga, Castelo Branco, and Aveiro - more than 20 percent of the entire labor force is working in vulnerable manufacturing sectors. Guarda, Leiria, and Porto also will suffer large adjustment cost, though to a lesser degree.

While long-run equilibrium wage rates are consistent with different levels of emigration, the actual levels depend on the verified inflow of capital. Different ratios of labor outflow to capital inflow have different welfare implications. Massive population outflows have social costs to those remaining behind, such as desertification of some areas, decreases in the average qualifications of the labor force, separation of families, and aging of the population. Economic policy should, therefore, be directed at increasing labor productivity in Portugal to reduce the incentives to emigrate.

The level of labor productivity depends on the capital-to-labor ratio, qualifications of the labor force, and technological innovation. Therefore, government should attract new investment, provide training to the labor force, and encourage the creation of firms that use new technologies. Obstacles such as bureaucratic requirements for the creation and closure of firms, delays in the court system, and poor quality of infrastructures, particularly communications, inhibit investment in Portugal. Removing these obstacles should be a high priority of government policy. Equally important should be an increase in the quality of human capital and technology. These can be achieved through investments in education, research, and professional training.

In turn, Portuguese firms should spend more on research and development, strengthen their financial structure, and adopt new and more flexible systems of production, management, and distribution. More in-depth discussions of these policy recommendations can be found in Straubhaar (1988), Seabra and Pereira (1991), and Baer and Leite (1991).

${ }^{4}$ The values represent a lower bound because only industries with more than $\mathbf{3 , 0 0 0}$ workers were considered and because a large international trade is a sufficient, but not necessary, condition for an elastic demand to prevail. 


\section{References}

Baer, W., and A. N. Leite. 1991. The peripheral economy, its performance in isolation and with integration: The case of Portugal. Lisbon: Universidade Nova de Lisboa Faculdade de Economia Working Paper 176.

Barosa, J. P., and P. T. Pereira. 1989. Economic integration and labor flows: The European Single Market Act and its consequences. Lisbon: Universidade Nova de Lisboa Faculdade de Economia Working Paper 123.

Barosa, J. P., and P. T. Pereira. 1992. Labor supply in an environment with emigration. In The Portuguese economy towards 1992, eds. J. G. Amaral, D. Lucena, and A. S. Mello. Boston: Kluwer.

Branco, F., and A. S. Mello. 1992. Why are wages in Portugal lower than elsewhere in the EEC? In The Portuguese economy towards 1992, eds. J. G. Amaral, D. Lucena, and A. S. Mello. Boston: Kluwer.

Buigues, P., F. Ilzkovitz, and J. F. Lebrun. 1990. The impact of the internal market by industry sector: The challenge for the member states. Brussels: Commission of the European Communities.

Burda, M., and C. Wyplosz. 1992. Human capital investment and migration in an integrated Europe. European Economic Review 36: 677-84.

Corado, C., and J. Melo. 1985. A simulation model to estimate the effects of Portugal's entry into the common market. Economia 9: 403-30.

Donges, J. B., and K. W. Schatz. 1985. The Iberian countries facing European Community membership: Starting conditions for their industries. Weltwirtschaftliches Archiv 121: 756-78.

Donges, J. B., and K. W. Schatz. 1989. The Iberian countries in the EEC: Risks and chances for their manufacturing industries. In European integration and the Iberian economies, ed. G. N. Yannopoulos. Hong Kong: Macmillan.

Ehrenberg, R., and R. Smith. 1988. Modern labor economics. 3d ed. Glenview: Scott, Foresman and Co.

Elliott, R. 1991. Labor economics. London: McGraw-Hill.

Instituto Nacional de Estatística. 1987. Estatstícas Industriais. Lisboa: Instituto Nacional de Estatística.

McConnel, C., and S. Brue. 1989. Contemporary labor economics. 2d ed. Singapore: McGraw-Hill.

Markusen, A. R., H. Noponen, and K. Driessen. 1991. International trade, productivity, and U.S. Regional job growth: A shift-share interpretation. International Regional Science Review 14: 15-39.

Martin, F. 1991. Measuring the impact of free trade: Local analysis versus regional and national models. International Regional Science Review 14: 1-14.

Pereira, A. M. 1989. Trade-off between emigration and remittances in the Portuguese economy. Lisbon: Universidade Nova de Lisboa Faculdade de Economia Working Paper 129.

Plummer, M. 1991. Efficiency effects of the accession of Spain and Portugal to the European Community. Journal of Common Market Studies 29: 317-25.

Raffelhuschen, B. 1992. Labor migration in Europe: Experiences from Germany after unification. European Economic Review 36: 1453-71.

Seabra, M. C., and P. T. Pereira. 1991. Reflexões sobre a política microeconómica do estado face a 1992. Economia 15: 245-53.

Straubhaar, T. 1988. International labour migration within a common market: Some aspects of the European Community experience. Journal of Common Market Studies 27: 45-62. 


\section{Appendix}

Suppose

$D(p)=$ demand faced by Portuguese firms,

$S^{F}(p)=$ supply by foreign firms,

$D^{F}(p)=$ demand of foreign consumers,

$D^{H}(p)=$ demand of Portuguese consumers, and

Then,

$S^{H}(p)=$ supply by Portuguese firms.

$$
D(p)=D^{H}(p)+D^{F}(p)-S^{F}(p),
$$

and in equilibrium,

$$
D(p)=S^{H}(p) \text {. }
$$

Let $D^{F}(P)-S^{F}(P)$ denote net trade, $T$, which will be greater than zero for Portuguese exports and less than or equal to zero for imports. Hence,

$$
D(p)=D^{H}(p)+T(p) .
$$

Taking the derivatives,

$$
\frac{d D(p)}{d p}=\frac{d D^{H}(p)}{d p}+\frac{d T(p)}{d p}
$$

or

$$
\eta_{\mathrm{D}}=\left(\mathrm{D}^{\mathrm{H}} / \mathrm{D}\right) \eta_{\mathrm{D}^{\mathrm{H}}}+(\mathrm{T} / \mathrm{D}) \eta_{\mathrm{T}},
$$

where $\eta_{\mathrm{D}}$ is the elasticity of demand faced by Portuguese firms, $\eta_{\mathrm{D}^{\mathrm{H}}}$ is the elasticity of demand by Portuguese consumers, $\eta_{\mathrm{T}}$ is the elasticity of trade, and equilibrium is assumed.

Substituting $\mathrm{D}^{\mathrm{H}}$,

$$
\eta_{\mathrm{D}}=\eta_{\mathrm{D}^{\mathrm{H}}}+(\mathrm{T} / \mathrm{D})\left(\eta_{\mathrm{T}}-\eta_{\mathrm{D}^{\mathrm{H}}}\right) \text {. }
$$

For tradable goods, $\eta_{\mathrm{T}}$ is near infinity, which implies that its value will dominate the overall elasticity, $\eta_{\mathrm{D}}$, unless $\mathrm{T} / \mathrm{D}=0$. Hence, a value for $T / D$ different from zero is a sufficient condition for $\eta_{D}$ to be large, which in turn implies market vulnerability. 